\title{
The cellular and molecular mechanisms by which insulin influences breast cancer risk and progression
}

\author{
David P Rose and Linda Vona-Davis
}

Department of Surgery and Breast Cancer Research Program, Mary Babb Randolph Cancer Center, West Virginia University, PO Box 9238, Morgantown, West Virginia 26506, USA

(Correspondence should be addressed to L Vona-Davis; Email: Ivdavis@ hsc.wvu.edu)

\begin{abstract}
Epidemiological studies have related hyperinsulinemia and type 2 diabetes to an increased breast cancer risk, an aggressive and metastatic phenotype, and a poor prognosis. Furthermore, diabetic retinopathy arises from pathological angiogenesis, which is also essential for breast cancer growth and metastasis. Insulin stimulates the proliferation of some human breast cancer cell lines in vitro by mechanisms that use both the phosphatidylinositol-3 kinase and the mitogen-activated protein kinase/Akt signaling pathways; it is also a cell survival (anti-apoptotic) agent and enhances tumor cell migration and invasive capacity. Hyperinsulinemia affects breast cancer cells via the endocrine system, but experimental studies suggest the importance of paracrine mechanisms operating by the effects of insulin on the secretion of adipokines from tumor-associated adipose tissue. In such a system, one adipokine, leptin, has stimulatory paracrine effects on breast cancer cell proliferation and survival, while a second, adiponectin, is inhibitory. Leptin, vascular endothelial growth factor, another insulin-regulated adipokine, and insulin itself also stimulate angiogenesis. Insulin has complex interactions with estrogens: it induces adipose stromal cell aromatase and tumor cell sex steroid hormone receptor expression and suppresses sex hormonebinding globulin, which may enhance estrogen synthesis and bioactivity with consequent promotion of estrogen-dependent breast cancer. All these actions influence the later steps in breast cancer development but genetic studies are also revealing connections between gene abnormalities related to type 2 diabetes and the initiation stage of breast carcinogenesis. Understanding the various mechanisms by which insulin participates in breast cancer cell biology provides opportunities for novel approaches to treatment.
\end{abstract}

Endocrine-Related Cancer (2012) 19 R225-R241

\section{Introduction}

Breast cancer is the most commonly occurring cancer in American women, with the exception of nonmelanomatous skin cancer, and is second only to lung cancer as the most common cause of cancerrelated deaths (American Cancer Society 2011). There is also a high prevalence of diabetes in the United States; it was estimated that in 2005-2006, 7.7\% of the population aged 20 years or older had been diagnosed as being diabetic and another $5.1 \%$ had unrecognized diabetes (Cowie et al. 2006).

There are broadly two forms of diabetes mellitus: in type 1 , diabetes is diagnosed most often in childhood and adolescence and results from an absolute deficiency of insulin that arises from autoimmune destruction of the pancreatic $\beta$-cells. Type 2 diabetes, which constitutes $\sim 95 \%$ of all cases (American Diabetic Association 2012), develops most often in later life but, together with obesity, is exhibiting an increasing prevalence in children and young adults. An autoimmune-related loss of $\beta$-cells is not involved, but both a reduction in insulin secretion and a metabolic resistance to insulin action are present and responsible for decreased glucose peripheral uptake and increased hepatic glucose production. In the preclinical and early clinical stages of type 2 diabetes, a high plasma insulin concentration features prominently among the biochemical abnormalities. 
However, despite the presence of hyperinsulinemia, longitudinal studies demonstrated that compromised $\beta$-cell function is present in prediabetics years before the onset of type 2 diabetes (Festa et al. 2006).

Obesity is also a risk factor for postmenopausal breast cancer (Rose et al. 2004) and is also causally associated with insulin resistance and an increased risk for type 2 diabetes. In studies that included analyses with statistical adjustments for confounding, hyperinsulinemia and type 2 diabetes were shown to be independent risk factors for postmenopausal breast cancer (reviewed by Vona-Davis \& Rose (2012)). A meta-analysis of 20 studies from nine different countries showed a $20 \%$ increase in breast cancer risk in women with diabetes compared with nondiabetics, with adjustment for the BMI having no significant effect on this result: the relationship was confined to women who were beyond the menopause (Larsson et al. 2007). A large prospective study by Michels et al. (2003) confirmed the positive relationship in postmenopausal women but actually found a trend for a negative relationship for premenopausal women.

Our present purpose is not to examine the epidemiological evidence that type 2 diabetes is a risk factor for breast cancer and causally related to a poor prognosis, as this has been the subject of a number of recently published reviews (for example, Wolf et al. (2005), Xue \& Michels (2007), Vigneri et al. (2009), Peairs et al. (2011) and Johnson et al. (2012)). Here, the focus is specifically on insulin as a hormonal factor in breast cancer biology and its actions on tumor cell growth and invasion and tumor-related angiogenesis. The mechanisms involved are explored, with a discussion on insulin as a direct breast cancer cell and vascular endothelial cell mitogen and antiapoptotic agent and as a potential endocrine regulator of three breast cancer-associated adipokines that are concerned with paracrine and autocrine growth control. In addition, clinical aspects of insulin-estrogen interactions are discussed.

\section{Hyperinsulinemia}

\section{Insulin synthesis, secretion, and response to peripheral resistance}

The primary translation product of the insulin gene is preproinsulin, a 110 amino acid peptide that is processed in the pancreatic $\beta$-cells to yield proinsulin: this, in turn, loses a connecting peptide (C-peptide) to produce insulin. Plasma proinsulin was shown by Zethelius et al. (2003) to be a biomarker of type 2 diabetes risk and is a highly specific marker for insulin resistance (Pfutzner et al. 2004).

Insulin pathophysiology has two components: one is functional and arises from abnormal insulin secretion kinetics and reduced insulin sensitivity and the other is manifestly pathological in the sense that there is a quantifiable diminution in pancreatic $\beta$-cell mass with heightened apoptotic activity (Guillausseau et al. 2008). A genetic component to type 2 diabetes risk is now well recognized (Zeggini \& McCarthy 2007). In individuals with a genetically determined risk for type 2 diabetes, loss of $\beta$-cell activity results in the failure of insulin secretion to compensate for tissue resistance and in consequence there is worsening hyperglycemia. However, in situations where $\beta$-cell function is maintained, there is sustained hyperinsulinemia, but the plasma glucose concentration remains normal. So, for example, in obesity, not complicated by type 2 diabetes insulin resistance is compensated for by an increase in $\beta$-cell mass but the elevated insulin production may result in hyperinsulinemia with its potentially adverse effect on breast cancer risk. For those who do develop diabetes, hyperinsulinemia may predate clinical disease by at least $10-15$ years (Lundgren et al. 1990).

\section{Breast cancer}

There is a wide range of biological differences between breast cancers arising in premenopausal and postmenopausal women, which are expressed clinically in the relatively high prevalence of estrogen receptor (ER)-negative, hormone-independent, aggressive tumors in premenopausal breast cancer. Upper body obesity is a risk factor for postmenopausal breast cancer, whereas in premenopausal women, adiposity does not usually enhance risk and may actually exert a protective effect (van den Brandt et al. 2000, Lahmann et al. 2004).

Gunter et al. (2009) compared the fasting serum insulin concentrations on entry into a prospective study of 835 nondiabetic postmenopausal women who subsequently developed breast cancer and 816 women who remained cancer free. They found a positive association with breast cancer risk: the hazard ratio for the highest compared with the lowest quartile of insulin values was 1.46 (95\% confidence interval: 1.00-2.13); Ptrend $=0.02$. In women participating in the Women's Health Initiative Study, the determination of fasting insulin concentrations was repeated at intervals during the follow-up period (Kabat et al. 2009). Women with serum insulin levels in the upper tertile were more than twice as likely to develop breast 
cancer compared with those in the lowest tertile; moreover, the relationship between the fasting serum insulin concentration and breast cancer risk held true for lean postmenopausal women, indicating a mechanism independent of the effects of obesity. The serum glucose and insulin levels were also used in this study to determine the homeostasis model assessment (HOMA)-insulin resistance index. This showed a positive association between the HOMA-insulin resistance and breast cancer risk, as did a prospective study performed in Italy by Sieri et al. (2012). High fasting serum insulin concentrations and indices of insulin resistance were also demonstrated by Goodwin et al. $(2002,2009)$ to be associated with a poor prognosis in women with early breast cancer.

In summary, epidemiological studies have demonstrated a positive association between hyperinsulinemia and breast cancer risk in nondiabetic postmenopausal women which, with the usual concern that there may be some residual confounding in the statistical evaluation, appears to be independent of the degree of adiposity. Before the menopause, the situation is much more complex. It was discussed in detail recently by Vona-Davis \& Rose (2012), but the overall conclusion from the published results of both prospective and case-control studies is that there is no consistent association between premenopausal breast cancer and the serum insulin.

\section{Insulin: a direct breast cancer cell mitogen and cell survival factor}

\section{Insulin, its receptor, and signaling pathways}

Although insulin is involved primarily in the regulation of carbohydrate, lipid, and protein metabolism, it also has a significant role as a growth factor: it stimulates cell mitosis and migration and inhibits apoptosis, effects that may actually be increased under conditions of insulin resistance and consequent impairment of insulin-regulated metabolic pathways. In general, the metabolic effects of insulin such as glucose transport are mediated by way of the phosphatidylinositol 3-kinase (PI3K) pathway, whereas the mitogenic effects of insulin involve the activation of Ras and the mitogen-activated protein kinase (MAPK) pathway (Fig. 1). When insulin resistance with hyperinsulinemia is present, the capacity for stimulation of the PI3K pathway by insulin is lost, but there is enhanced MAPK activation and an increase in insulin-induced prenylation of Ras protein (Gallagher \& LeRoith 2010, Draznin 2011). As will be seen later, this distinction between the two signaling pathways is not absolute and is not a consistent feature of the mitogenic effects of insulin on cancer cells.

Specific insulin receptors (IRs) are present at the surface of most cells, although the levels are particularly high on targets for insulin action. The IR is a member of the tyrosine kinase family of receptors and is a heterotetramer composed of two extracellular $\alpha$-subunits and two transmembrane $\beta$-subunits that are linked by disulfide bonds. Insulin binds to the $\alpha$-subunits to activate the tyrosine kinase of the $\beta$-subunits. Amplification of the IR tyrosine kinase results in the rapid phosphorylation of several proteins, including Shc adaptor protein 1 and members of the IR substrate (IRS) family. One of these, IRS1, acts as an intermediate downstream docking protein and forms a scaffold for the downstream partitioning of the PI3K and MAPK signaling pathways (Fig. 1). In this manner, the IRS adaptor protein coordinates signaling mediated by hormones and growth factors, including insulin and insulin-like growth factor (IGF1), as well as the adipokine leptin (reviewed by Fruhbeck (2006)), downstream of the individual activated cell surface receptors. Binding of IRS to IR activates the PI3K pathway, with further activation of Akt, and binding of Shc adaptor protein 1 to IR activates the Ras/MAPK pathway (Fig. 1). The expression of IRS1 is increased in breast cancer tissues, with particularly high levels in well-differentiated compared with poorly differentiated tumors (Sisci et al. 2007).

\section{Breast cancer cell IR and mitosis}

The significance of the IR to cancer cell biology and the implications for cancer treatment and control were the subject of a recent in-depth review by Belfiore \& Malaguarnera (2011) and will only be discussed briefly here. In a study of 191 patients, higher primary breast cancer IR levels were found to be associated with biomarkers of a good prognosis, including low histological grade, progesterone receptor (PR) expression, and an absence of regional lymph node involvement, and with prolonged periods of distant disease-free survival (Mulligan et al. 2007). The IR is distinct from the receptor for IGF1; cross-binding of the two ligands does occur but with low affinities, and so at physiological concentrations, insulin and IGF1 activate separate biological responses. Nevertheless, the receptors do share the same adaptor molecules that provide entry to the same signaling pathways and this commonality may limit the efficacy of small-molecule IGF1 receptor inhibitors as chemotherapeutic agents (Buck et al. 2010). 


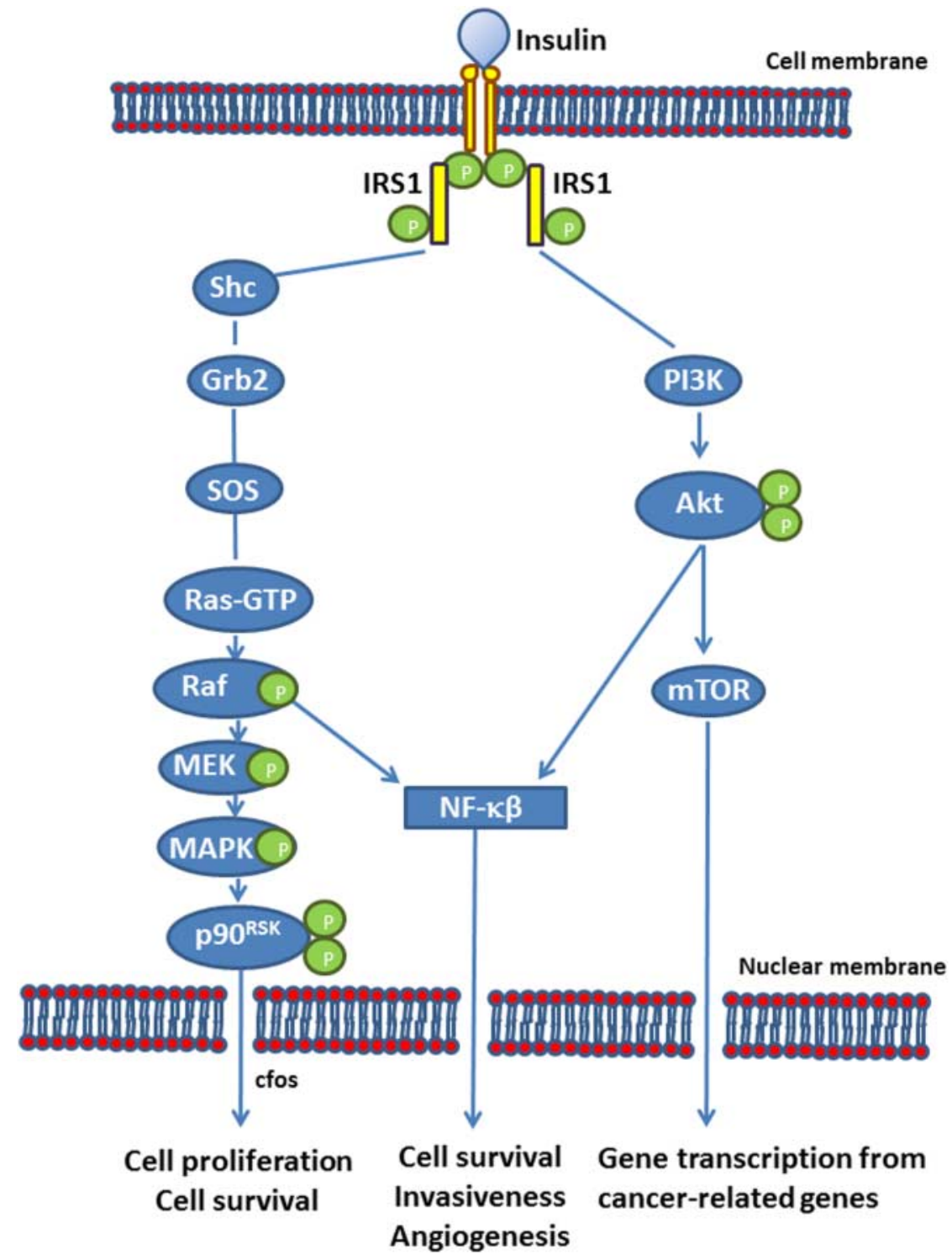

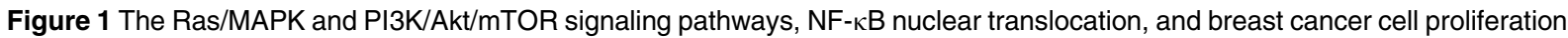

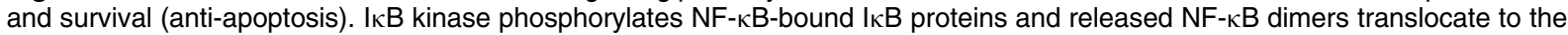
nucleus. PI3K activation of Akt stimulates NF- $\kappa$ B activity, which also occurs via Ras/Raf. IRS1, insulin receptor substrate-1; MEK, mitogen-activated protein kinase kinase; MAPK, mitogen-activated protein kinase; PI3K, phosphatidylinositol 3-kinase; mTOR, mammalian target of rapamycin; NF- $\mathrm{B}$, nuclear factor $\kappa$-light chain enhancer of activated $\mathrm{B}$ cells. Full colour version of this figure available via http://dx.doi.org/10.1530/ERC-12-0203.

Although proinsulin is present in the plasma and occurs at high levels in type 2 diabetes, it was regarded as having only weak affinity for the IR, little biological activity, and of no relevance to breast cancer biology. However, the situation has changed with the demonstration that IR actually occurs in two splice variants, isoforms IR-A and IR-B, and that IR-A is particularly active in mitotic signaling (reviewed by Belfiore et al. (2009)). Sciacca et al. (1999) found that IR-A was dominant in breast cancer tissues and that its activation by either insulin or IGF2 stimulated mitosis. Later, this same group showed that in the MDA-MB-157 human breast cancer cell line, proinsulin binds with high affinity to IR-A and stimulates phosphorylation of the receptor (Malaguarnera et al. 2012).

Numerous cell culture experiments have been performed to examine the effect of insulin on breast cancer cell growth using the assessment of $\left[{ }^{3} \mathrm{H}\right]$ thymidine incorporation or change in cell number. Although only a few cell lines were used, these showed 
consistently that insulin added to serum-free medium promoted growth of the ER-positive MCF-7, T47D, and ZR-75-1 human breast cancer cell lines (Table 1). Ogasawara \& Sirbasku (1988) compared the effects of insulin and IGF1 on MCF-7 cell proliferation and found that insulin and IGF1 were mitogenic, although IGF1 was more potent. The T47D cell line was also stimulated by both insulin and IGF1, but only at concentrations that were 15-20 times those required for the MCF-7 cells. Milazzo et al. (1992) showed that MCF-7 and ZR-75-1 breast cancer cells had IR levels that were five- and three-fold of those present in an untransformed human breast epithelial cell line or T47D breast cancer cells; in all cases, insulin stimulated IR tyrosine kinase activity and thymidine incorporation.

There have been several investigations directed at understanding the influence of insulin on the PI3K and MAPK signaling pathways and mitosis in breast cancer cell lines in vitro (Table 2) and mammary tumor development in vivo. Chappell et al. (2001) showed that the stimulation of MCF-7 cell proliferation by insulin required activation of $\mathrm{PI} 3 \mathrm{~K}$ and that this response was accompanied by increased expression of cyclin D1, a PI3K-regulated protein involved in cell cycle progression. Novosyadlyy et al. (2010) reproduced the relationship between hyperinsulinemia and breast cancer development using a nonobese but insulin-resistant and hyperinsulinemic, transgenic MKR mouse model. They bred double transgenic PyVmT/MKR female mice that developed mammary ductal hyperplasia and, later, IR-expressing carcinomas. Signaling by the PI3K, but not the MAPK, pathway was increased in the mammary tissues, and tumorigenesis was suppressed by treatment with a small-molecule tyrosine kinase inhibitor that blocked signaling via the IR.

In contrast, the growth response to insulin of other breast cancer cell phenotypes appears to involve exclusively the MAPK signaling pathway. The ZR-75-1 cell line does express PI3K protein, which is functional as demonstrated by its response to EGF, but in experiments performed by Gliozzo et al. (1998), insulin-induced mitosis was not associated with a change in PI3K activity nor blocked by a PI3K inhibitor; it was, however, accompanied by an increase in Shc tyrosine phosphorylation and MAPK activity and suppressed in the presence of an inhibitor of MAPK.

The effects of insulin on ER-negative human breast cancer cell lines are quite complex and their interpretation is limited by the number of cell lines. Gliozzo et al. (1998) reported that cultured MDAMB-157 cells, which do not express ER (Sawatsri et al. (2001), showed a strong mitogenic response to exogenous insulin. This stimulation was suppressed by a pharmacological inhibitor of MAPK kinase, which phosphorylates and activates MAPK (Fig. 1), whereas inhibition of PI3K produced only a 'blunting' of the growth response, results consistent with a critical role for the Ras/MAPK pathway. This cell line was also used by Malaguarnera et al. (2012) to demonstrate that proinsulin and insulin have similar stimulatory effects on MAPK activation and breast cancer cell proliferation and migration.

Table 1 The influence of insulin on the growth of human breast cancer cell lines in vitro and their estrogen receptor (ER) status

\begin{tabular}{|c|c|c|c|}
\hline \multirow[b]{2}{*}{ Cell lines (ER status) } & \multicolumn{2}{|c|}{ Insulin growth stimulation } & \multirow[b]{2}{*}{ Reference } \\
\hline & {$\left[{ }^{3} \mathrm{H}\right]$ thymidine } & Cell number & \\
\hline \multirow[t]{4}{*}{ MCF-7 (ER+) } & + & Not done & Osborne et al. (1978) \\
\hline & Not done & + & Ogasawara \& Sirbasku (1988) \\
\hline & + & Not done & Milazzo et al. (1992) \\
\hline & & & Sepp-Lorenzino et al. (1994) \\
\hline \multirow[t]{3}{*}{ T47D $(\mathrm{ER}+)$} & Not done & + & Ogasawara \& Sirbasku (1988) \\
\hline & + & Not done & Milazzo et al. (1992) \\
\hline & + & Not done & Belfiore et al. (1996) \\
\hline \multirow[t]{4}{*}{ ZR-75-1 (ER+) } & + & Not done & Osborne et al. (1978) \\
\hline & Not done & + & Ogasawara \& Sirbasku (1988) \\
\hline & + & Not done & Milazzo et al. (1992) \\
\hline & Not done & + & Gliozzo et al. (1998) \\
\hline \multirow[t]{3}{*}{ MDA-MB-231 (ER-) } & \pm & Not done & Osborne et al. (1978) \\
\hline & - & - & Costantino et al. (1993) \\
\hline & \pm & Not done & Belfiore et al. (1996) \\
\hline MDA-MB-468 (ER-) & Not done & \pm & Sepp-Lorenzino et al. (1994) \\
\hline MDA-MB-157 (ER-) & Not done & $\overline{+}$ & Gliozzo et al. (1998) \\
\hline
\end{tabular}

\pm , little or no stimulation. 
Table 2 Insulin-induced responses of the PI3K and MAPK signaling pathways in breast cancer cell lines

\begin{tabular}{lllllll}
\hline & & & \multicolumn{3}{c}{ Activation by insulin } \\
\cline { 4 - 7 } Cell line & ER status & Insulin growth & IR & IRS1 & PI3K & MAPK/rasGTP \\
\hline MCF-7 & Positive & Yes (1, 2, 4, 5) & Yes (2) & Yes (4) & Yes (3, 5) & rasGTP yes (4) \\
ZR-75-1 & Positive & Yes (1-3) & No (3) & No (3) & No (3) & MAPK yes (3) \\
MDA-MB-157 & Negative & Yes (3) & Yes (3) & NA & Yes (3) & MAPK yes (3) \\
MDA-MB-468 & Negative & No (4) & Yes (4) & Yes (4) & Yes (4) & rasGTP no (4) \\
MDA-MB-231 & Negative & No (1,6) & Low (6) & NA & NA & NA \\
\hline
\end{tabular}

The numbers in parentheses indicate the relevant references as follows: (1) Osborne et al. (1978); (2) Milazzo et al. (1992);

(3) Gliozzo et al. (1998); (4) Sepp-Lorenzino et al. (1994); (5) Chappell et al. (2001); (6) Belfiore et al. (1996).

aMAPK-stimulated activity; rasGTP increased; NA, not available.

The effects of insulin have also been examined in two other ER-negative human breast cancer cell lines, but in contrast to MDA-MB-157 cells, neither showed a significant mitogenic response (Table 2). SeppLorenzino et al. (1994) performed insulin growth experiments with the MDA-MB-468 cell line and found that although the IR was autophosphorylated and there was an activation of IRS and PI3K, these changes were not accompanied by a proliferative response; significantly, there was no activation of Ras by insulin, although epidermal growth factor, which does stimulate MDA-MB-468 cell growth, did produce an increase in rasGTP. The MDA-MB-231 human breast cancer cell line possesses IR at levels similar to those present in some insulin-responsive breast cancer cell lines, but it exhibited minimal or no stimulation of thymidine incorporation or proliferation in vitro when cultured in the presence of added insulin (Table 1), a lack of response that Costantino et al. (1993) showed was associated with low IR tyrosine kinase activity.

The failure of insulin to induce a tyrosine kinase response may be associated with a high level of membrane glycoprotein PC-1 expression in MDA-MB-231 cells compared with other cell lines, including the ER-negative MDA-MB-157 cell line that does undergo an insulin-stimulated growth response (Belfiore et al. 1996). The expression of PC-1 was low in MCF-7 cells, but Belfiore et al. prepared clones with different levels of the protein and showed that the PC-1 activity was inversely correlated with IR autophosphorylation. These observations are of particular interest because PC-1, a phosphodiesterase present at particularly high levels in liver, skeletal muscle, and adipose tissue, interacts with the IR to inhibit insulin signaling; its overexpression is related to insulin resistance (Goldfine et al. 2008), and its suppression results in improved insulin sensitivity (Zhou et al. 2009).

\section{Anti-apoptosis}

Apoptosis, programmed cell death, is mediated by a series of protein factors that include the pro-apoptotic members of the Bcl-2 family and the caspase group of cysteine proteases. Bcl-2 itself, however, is one of the proteins that inhibit apoptosis. Upregulation of the Bcl-2 family member Bax results in increased activity of the caspases and enhanced apoptotic activity; inhibition of one of these enzymes, caspase-3, is part of the mechanism by which insulin exerts an antiapoptotic function. In addition to Bax, there are 11 other proteins with varying degrees of structural similarity to $\mathrm{Bcl}-2$; one, $\mathrm{Bad}$, is also downregulated by insulin with a resulting reduction in programmed cell death. The signaling of anti-apoptotic activity by insulin involves both the PI3K/Akt and MAPK pathways (Desbois-Mouthon et al. 2000, Park et al. 2000).

Insulin can impede the process of apoptosis in DNAdamaged untransformed breast epithelial cells (Merlo et al. 1995); a similar effect in transformed cells would serve to reinforce the increase in breast cancer cell number produced by enhanced mitotic activity. Teng et al. (2011) found that the long-acting insulin analog glargine produced a partial suppression of apoptosis in the MCF-7 breast cancer cell line, which was accompanied by downregulation of Bax and upregulation of Bcl-2 protein, and a similar anti-apoptotic effect of insulin, involving the PI3K pathway was observed in an endometrial cell line (Wang et al. 2012).

\section{Adipokines}

Adipokines are proteins, mostly growth factors and cytokines, that are synthesized in adipose tissue including the fat cells or adipocytes, the stromal cell proadipocytes, and the macrophages that infiltrate the adipose tissue mass. There are a number of adipokines that exert positive or negative effects on breast cancer cell growth and invasion; here, we focus 
on three: leptin, adiponectin, and vascular endothelial cell growth factor (VEGF). Sites of adipokine secretion include the general body adipose tissue mass, from which their entry into the systemic circulation provides for their endocrine activity; the adipocytes of the tumor capsule and the breast cancer cells themselves are sources of adipokines acting as paracrine and autocrine factors respectively. Figures 2 and 3 summarize these relationships and also the functional interactions that occur when they are coupled with the endocrine activity of insulin secreted from the $\beta$-cells of the pancreatic islets.

\section{Leptin}

Leptin is a pleiotropic protein secreted by both proadipocytes and adipocytes and activates both the Ras/MAPK and PI3K/Akt signaling pathways (Fruhbeck 2006). Plasma leptin concentrations are positively correlated with the BMI and are abnormally high in obese women (Rose et al. 2004). However, although obesity is a recognized risk factor for postmenopausal breast cancer and an association of hyperleptinemia with increased breast cancer risk was reported, later studies of plasma leptin levels in breast cancer have produced conflicting results (Vona-Davis \& Rose 2007). One possible explanation is that a paracrine mechanism pre-empts the endocrine role of leptinmediated stimulation of breast cancer development and progression; higher levels of leptin expression have been demonstrated in the adipocytes of the stromal capsule, which surrounds a breast tumor mass and this contributes to the cancer cell microenvironment (Celis et al. 2005).

Plasma leptin levels are elevated in type 2 diabetes and exhibit a positive correlation with the degree of insulin resistance that is independent of the BMI and body fat mass (Fischer et al. 2002, Wauters et al. 2003). Insulin regulates leptin availability by stimulating both new leptin synthesis and the release of leptin from pre-existing intracellular pools; this elevation in leptin levels involves interaction between insulin and glucocorticoids and is dependent on the

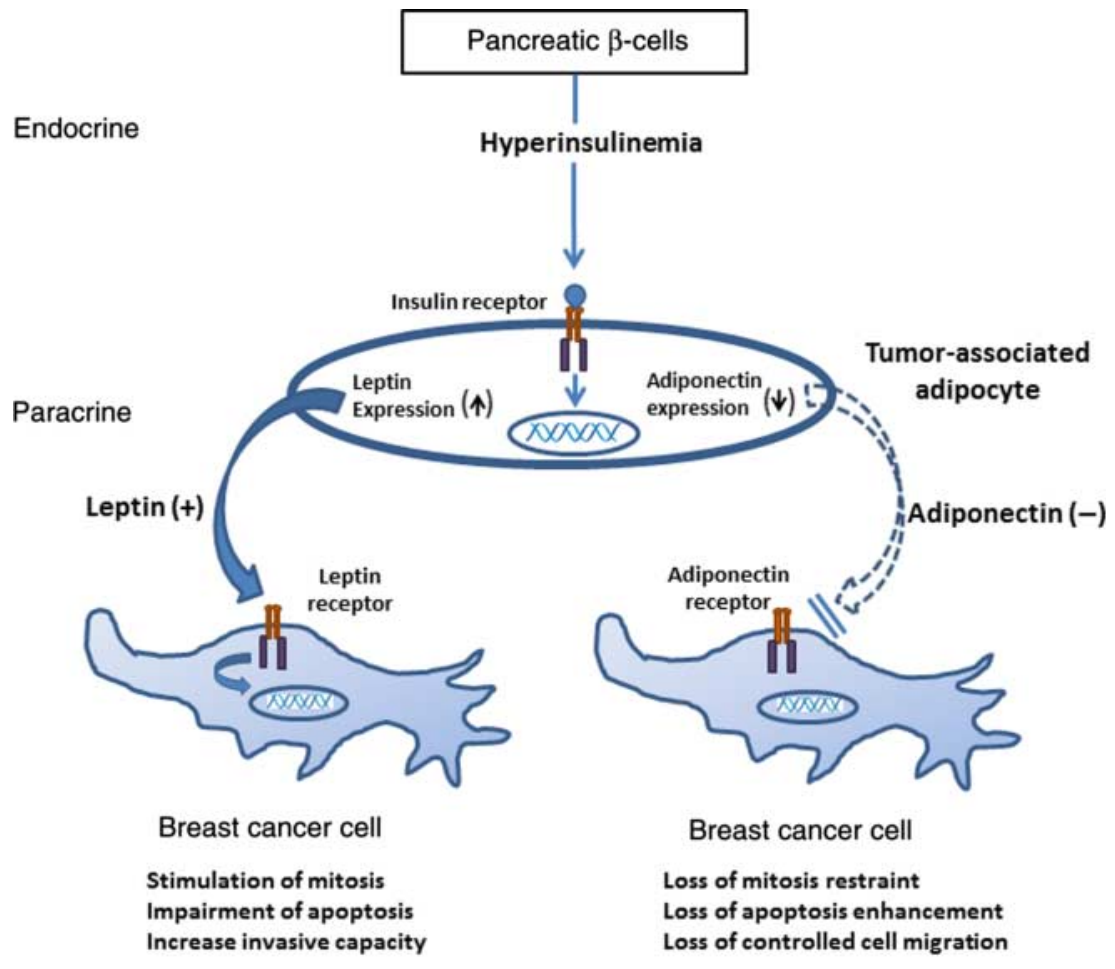

\section{Rapid breast cancer cell growth Increased invasive capacity}

Figure 2 The paracrine stimulation of breast cancer cell growth and invasion by leptin and inhibition by adiponectin and their enhanced activities by hyperinsulinemia. In the Figures, increases/stimulations are indicated by (open triangle) and deceases/inhibitions by (open down triangle). Full colour version of this figure available via http://dx.doi.org/10.1530/ERC-12-0203. 


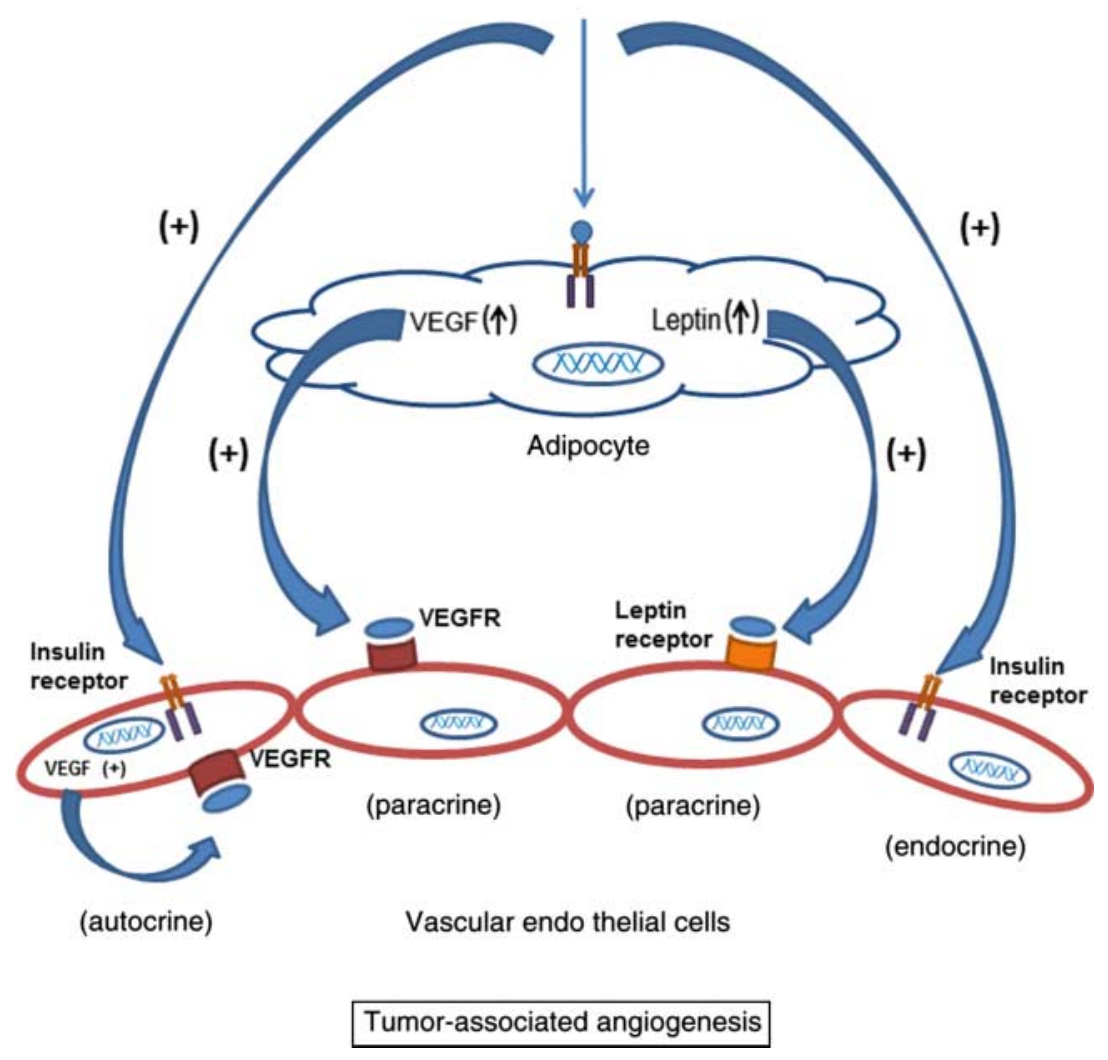

Figure 3 Insulin exerts a direct endocrine stimulation of vascular endothelial cell (VEC) proliferation and tube formation and indirect stimulation by inducing VEGF production in the VECs with its consequent binding to the VEC VEGF receptors and autocrine action resulting in mitogenesis and angiogenesis. Insulin action on peritumorous adipocytes also induces VEGF and leptin production, so promoting the paracrine activities of these angiogenic factors on tumor-associated VECs (Not shown for reasons of clarity is the potential for direct endocrine VEC stimulation by a high level of leptin synthesis in the adipose tissue mass remote from the tumor.). Full colour version of this figure available via http://dx.doi.org/10.1530/ERC-12-0203.

janus-activated kinase JAK/signal transducers and activators of transcription and the MAPK and PI3K/ Akt signaling pathways (Bradley \& Cheatham 1999, Cirillo et al. 2008).

Breast cancer cells possess leptin receptors, and leptin stimulates mitogenesis and also functions as an anti-apoptotic (survival) factor (Perera et al. 2008). In consequence, when hyperinsulinemia is present to provide an endocrine stimulus for leptin production by tumor-associated adipocytes, all the elements are in place for the establishment of an insulin-mediated, growth-promoting, paracrine loop between adipocytesecreted leptin and the leptin receptor-expressing breast cancer cell (Fig. 2). Furthermore, insulin, by way of both the PI3K and MAPK signaling pathways, can induce the overexpression of both leptin and its receptor in the human breast cancer cells themselves (Garofalo et al. 2006, Bartella et al. 2008), and so may contribute to an autocrine stimulation of breast cancer growth. Additionally, hyperleptinemia enhances aromatase activity resulting in increased estrogen synthesis, favoring cross talk between the leptin receptor and the ER $\alpha$ via PI3K/MAPK and JNK signaling pathways (Cirillo et al. 2008).

Leptin supports the angiogenic component of tumor development; like insulin, it stimulates vascular endothelial cell proliferation and capillary tube formation in vitro and angiogenesis in animal models (reviewed by Vona-Davis \& Rose (2009)) and may do so through an adipocyte-endothelial cell paracrine loop (Fig. 3). It should be noted that the paracrine effects are still considered speculative as the data for in vivo is different from cell culture. For example, in the fatless A-Zip/F1 mouse, adipose tissue and adipokines such as leptin, are unavailable for tumor development making insulin resistance and inflammation the main mechanisms accounting for tumor growth and progression (Hursting et al. 2007). 
Although leptin is produced primarily by adipocytes, it can also be secreted by fibroblasts, the principle component of stroma surrounding the tumor. The cancer-associated fibroblasts secrete leptin, which acts in a paracrine fashion to bind its receptor on mutant ER-expressing tumor cells creating an environment of cross talk between stroma and tumor (Barone et al. 2012).

\section{Adiponectin}

Adiponectin has activities under both physiological and pathological conditions that are largely in opposition to those of leptin. Plasma adiponectin concentrations show an inverse correlation with the BMI and are subnormal in obese women. Both the adiponectin protein levels in plasma (Weyer et al. 2001, Haluzik et al. 2004) and expression of the mRNA in adipose tissue (Statnick et al. 2000) are reduced in type 2 diabetes, changes that are a function of insulin resistance rather than of any coexisting adiposity. Hypoadiponectinemia has been associated with a BMI-independent increase in postmenopausal breast cancer risk (Mantzoros et al. 2004, Tian et al. 2007, Tworoger et al. 2007), and with high histological grade and advanced stage at the time of diagnosis (Miyoshi et al. 2003, Hou et al. 2007).

Studies showing an association of hypoadiponectinemia and breast cancer risk with hyperinsulinemia and insulin resistance are lacking. Duggan et al. (2011) performed a prospective investigation of the fasting serum adiponectin and insulin concentrations and the HOMA-insulin resistance index in stage I and II breast cancer patients and found that higher than median adiponectin concentrations were associated with a decreased risk of breast cancer mortality; the HOMAinsulin resistance values were positively correlated with both the breast cancer-specific and the all-cause mortality, as were, to a lesser degree, the fasting serum insulin levels.

There is experimental evidence that the level of adiponectin in the microenvironment influences the behavior of breast cancer cells. In cell culture experiments, exogenous adiponectin suppressed the proliferation and promoted apoptosis of both ER-positive (Dieudonne et al. 2006) and ER-negative (Dos Santos et al. 2008) breast cancer cells. Adiponectin also inhibited the invasive capacity of the highly metastatic ER-negative MDA-MB-231 breast cancer cell line in vitro and its metastasis in vivo (Wang et al. 2006). Similar to leptin, the paracrine actions of adiponectin remain speculative in vivo and do not support a role for adipose tissue and adiponectin in the enhancement of mouse mammary tumor development (Hursting et al. 2007).

One mechanism by which adiponectin levels are reduced in the tumor cell microenvironment is suggested by the demonstration that prolonged exposure of cultured adipocytes to insulin induces a dose-dependent, reversible, suppression of adiponectin expression (Fasshauer et al. 2002). This action of insulin observed in vitro may be a contributing factor to the development of mammary cancers in the nonobese diabetic mice with insulin resistance and hyperinsulinemia described by Novosyadlyy et al. (2010).

The postulated insulin-mediated cooperative paracrine-positive effects of increased leptin and negative effects of decreased adiponectin expression on breast cancer cell growth and invasion are summarized in Fig. 2.

\section{Vascular endothelial growth factor}

VEGF exerts its effects specifically on vascular endothelial cells for which it is a potent mitogen and anti-apoptotic factor and promoter of capillary tube formation (Veikkola \& Alitalo 1999, Ferrara 2001). It is synthesized in the preadipocytes and adipocytes where it is essential for vascularization and expansion of adipose tissue. In humans, the serum VEGF concentrations show a positive correlation with the BMI and elevated levels occur in obesity that are reversed with weight loss (Miyazawa-Hoshimoto et al. 2003); also, the plasma VEGF is higher in genetically obese mice and those with adipocyte implants compared with nonobese mice (Miyazawa-Hoshimoto et al. 2005). In addition to these relationships with adiposity, VEGF can act synergistically with leptin in promoting the angiogenic process (Cao et al. 2001).

\section{Insulin and angiogenesis}

Pathological angiogenesis provides the vascular support that is essential for cancer progression. It is essential for the growth of a solid tumor beyond a few millimeters in diameter and for the development of distant metastases, and in consequence, a high level of angiogenic activity in breast cancer provides a biomarker of a poor prognosis (Uzzan et al. 2004). There is considerable interest in the potential for inhibitors of angiogenic factors as cancer therapeutic agents, but specifically targeting VEGF may be inadequate, even though it is a specific mitogen for vascular endothelial cells, given the redundancy in proteins with angiogenic properties (Ribatti 2011), 
among which is insulin. Pathological angiogenesis is also responsible for some of the complications of type 2 diabetes, and its pharmacological inhibition is showing promise in the treatment of diabetic retinopathy and macular edema (Willard \& Herman 2012).

Microvascular epithelial cells possess IRs, including those of vessels associated with breast cancer stromal tissues (Rensing et al. 2010), and insulin has its own direct stimulatory effects on vascular endothelial cell migration and capillary-like tube formation, which Liu et al. (2009) showed take place by activation of the PI3K/Akt pathway. Insulin can also enhance neovascularization indirectly: first, it can induce VEGF expression in vascular endothelial cells (Yamagishi et al. 1999, Jiang et al. 2003), which results in the autocrine stimulation of microvascular endothelial cell growth and tube formation and second insulin stimulates VEGF synthesis and its release from adipocytes (Mick et al. 2002, Fain \& Madan 2005), which would provide for a paracrine interaction between the adipocytes of the peritumor adipose tissue and the tumor capsule and the tumor-associated vascular endothelial cells (Fig. 3). Both the PI3K/Akt and MAPK pathways are involved in this process, the two together being required for the sustained upregulation of VEGF under the influence of insulin (Jiang et al. 2003).

A similar endocrine action of insulin to enhance the paracrine promotion of angiogenesis by leptin is suggested by its known stimulation of leptin production in adipocytes combined with the proangiogenic activity of the adipokine itself (Fig. 3). The presence of a complex system of paracrine-mediated interactions involving insulin and the adipokines in the adipose tissue surrounding a breast cancer and the autocrine production of angiogenic factors by the tumor cells themselves suggests a particularly fruitful topic for future research. Of note is the report by Zhang et al. (2010) that angiogenesis became impaired around the periphery of solid tumors formed by breast cancer cells in the mammary fat pads of athymic nude mice when downregulation of the IR was induced while leaving IGF1 receptor expression intact and that this was associated with a diminished capacity for distant metastasis.

\section{Estrogen production and bioactivity}

Estrogens stimulate the proliferation of untransformed and neoplastic breast epithelial cells directly and also support tumor growth by promoting angiogenesis (Gupta \& Kuperwasser 2006). Obese postmenopausal women have elevated levels of estrogens, which are synthesized almost exclusively in adipose tissue stromal cells and can promote the development of ER-positive, estrogen-dependent, breast cancer by both endocrine and paracrine mechanisms (Vona-Davis \& Rose 2007, Bulun et al. 2012); a similar situation holds in postmenopausal women with type 2 diabetes. PR expression by these ER-positive tumors is induced by estradiol, a response that was shown in MCF-7 cells to be dependent on insulin (Katzenellenbogen \& Norman 1990). Panno et al. (1996) also showed that the arrest of MCF-7 cell growth in medium supplemented with serum stripped of steroids and protein growth factors was reversed by the addition of insulin or estradiol, that the two had synergistic stimulatory activity, and that insulin induced ER as well as PR expression and increased the binding capacity of the ER. Mauro et al. (2001) demonstrated that the expression and activation of ER enhanced insulin mitogenicity and that this was achieved by upregulation and enhanced function of IRS1 with increased PI3K/Akt and MAPK signaling.

Postmenopausal women with type 2 diabetes frequently have an increase in the plasma estrogens, which is distinct from any contribution arising from associated adiposity (Ding et al. 2007, Kalyani et al. 2009), and results from the enhancing effect of insulin on extraglandular estrogen biosynthesis. In the adipose tissue of women, but not men, insulin increases cytochrome P450 enzyme activity, so catalyzing the aromatization of the $\mathrm{C} 19$ steroid androstenedione to yield estrone, and also acts indirectly by enhancing the stimulatory effect of glucocorticoids on the aromatase enzyme system (McTernan et al. 2000); enzymatic reduction of this estrone then takes place to form estradiol.

In addition to the general stimulation of estrogen biosynthesis in the stromal cells of the visceral adipose tissue mass by insulin, which causes an elevation in the circulating estrogen levels and endocrine stimulation of ER-positive cells, there is the potential for paracrine stimulation originating specifically from high aromatase and 17- $\beta$-hydroxysteroid dehydrogenase activity in the stromal cells that form the tumor capsule. Furthermore, although not reported, it is feasible that insulin may stimulate the formation of estrogens from androstenedione in the breast cancer cells themselves, as these do express aromatase and 17- $\beta$-hydroxysteroid dehydrogenase (Sasano et al. 2006, Miki et al. 2007), so providing for autocrine stimulation of tumor cell proliferation.

Under physiological conditions, $30-50 \%$ of the plasma estradiol, the most biologically potent of the circulating estrogens, is bound to sex hormone-binding globulin (SHBG) and is functionally inert. Most of the 
estradiol that is not associated with SHBG is weakly bound to albumin, from which it readily dissociates to become biologically available, as is the $1-2 \%$ that normally circulates free of any protein binding (Rose 1993). Low concentrations of SHBG occur in women with hyperinsulinemia and insulin resistance, when they indicate a high risk of type 2 diabetes (Lindstedt et al. 1991, Haffner et al. 1993). Elevated bioavailable estradiol and reduced SHBG levels in type 2 diabetes are independent of the BMI (Golden et al. 2007, Kalyani et al. 2009), as they are when present in association with increased postmenopausal breast cancer risk (Kaaks et al. 2005).

\section{Commentary}

The complex interacting mechanisms by which insulin may promote breast cancer development and progression are summarized in Fig. 4. Insulin is involved in the promotional stage of breast tumorigenesis and progression to expression of the metastatic phenotype, rather than initiation and neoplastic transformation of the breast epithelial cell. Type 2 diabetes-related breast cancer occurs typically in women beyond the menopause, but whether this is due to a favorable hormonal environment, or the age at onset of, and length of exposure to insulin resistance, or that hyperinsulinemia is required for the promotion of initiated breast epithelial cells still remains uncertain. The question does have implications for breast cancer prevention because type 2 diabetes is occurring with increasing frequency in children and young adults. It does need to be stressed that the various events described in this review to make the connections between insulin action and the endocrine, paracrine, and autocrine activities of the adipokines have been established by laboratory experimentation, but their translational significance for human breast cancer requires further study.

Future studies should be directed at the interaction of environmental factors, such as the endocrine disturbances of obesity and type 2 diabetes, and genetic abnormalities. For example, variants of the gene that encodes transcription factor 7-like 2 (TCF7L2) have been associated with increased risk not only for type 2 diabetes (Zeggini \& McCarthy 2007), but also for breast cancer (Burwinkel et al. 2006, Naidu et al. 2011). These relationships are supported by experimental studies showing that $T C F 7 L 2$ regulates hepatic glucose production (Norton et al. 2011), part of the

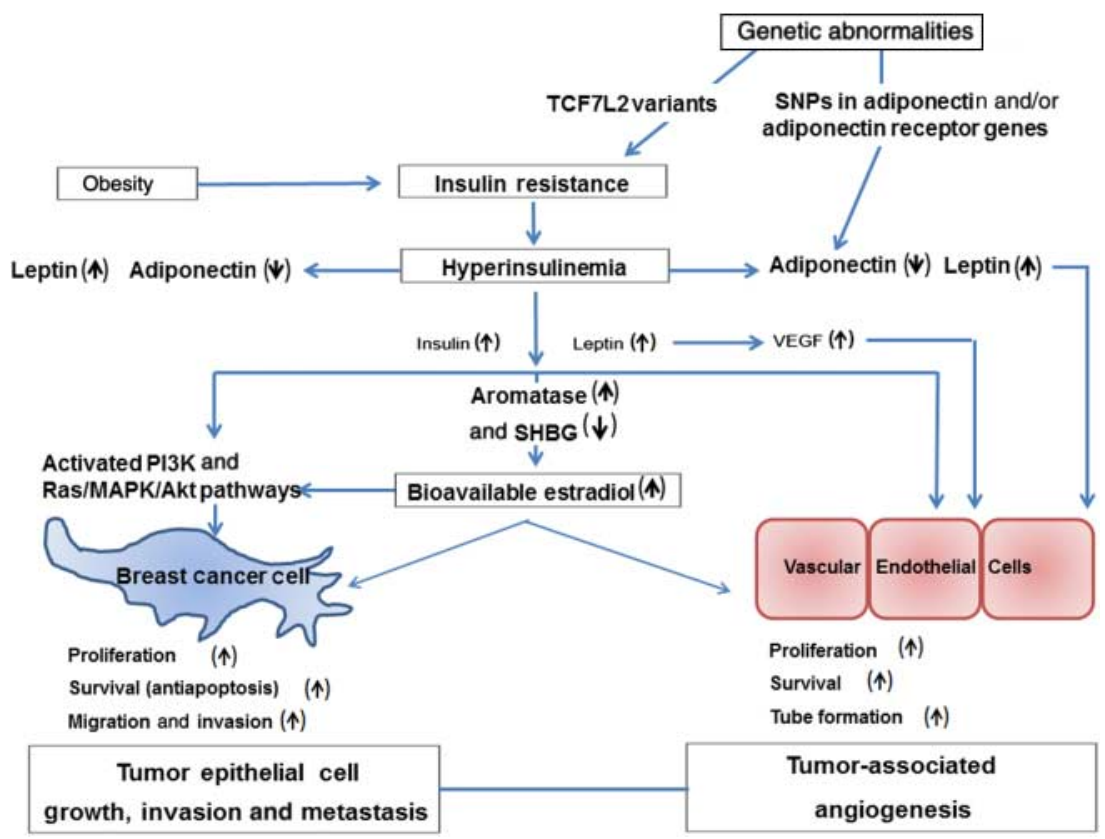

Figure 4 Insulin resistance-associated elevations in circulating insulin levels and insulin-inducible adipokine secretions in promoting breast cancer growth, invasion, and metastasis. These are achieved directly by the endocrine activity of insulin itself in stimulating insulin receptor-expressing tumor cell proliferation, survival, and metastatic capacity, enhancing estrogen action on tumor cells, and stimulating tumor-associated angiogenesis. Indirectly, insulin may increase these same effects on tumor behavior by stimulation of leptin and VEGF production, and suppression of adiponectin synthesis, in adipocytes with altered endocrine, paracrine, and autocrine actions by the adipokines. Full colour version of this figure available via http://dx.doi.org/10.1530/ERC-12-0203. 
Wnt $/ \beta$-catenin signaling cascade, which contributes to pancreatic $\beta$-cell regulation (Le Bacquer et al. 2011).

Understanding the biochemical mechanisms by which insulin influences breast cancer progression offers some novel approaches to chemotherapy. Metformin, the standard first-line pharmaceutical treatment for type 2 diabetes, is currently undergoing evaluation as adjuvant therapy in breast cancer; in preclinical studies, it was shown to not only reduce elevated blood insulin concentrations but also to stimulate AMP-activated protein kinase activation in breast cancer cells, with inhibition of mTOR (Dowling et al. 2007), and to inhibit aromatase activity in breast adipose stromal cells (Brown et al. 2010). Downstream of the IR, several inhibitors of the PI3K/Akt pathway are under investigation in animal models and clinical trials (Gallagher et al. 2011, Hernandez-Aya \& Gonzalez-Angulo 2011). How the potential therapeutic responses in breast cancer patients relate to the presence of insulin resistance and hyperinsulinemia is unclear, but in the nonobese MKR mouse with hyperinsulinemia and mild glucose intolerance, the mammary tumors show increased activation of the PI3K/Akt/mTOR pathway and pharmacological PI3K inhibition reduced tumor growth. Fierz et al. (2010) investigated the mTOR pathway in the MKR model and demonstrated that inhibition of mammary tumor growth occurs in mice treated with rapamycin.

We need a better understanding of the relationship between ER status, tumor estrogen dependence, and the coexistence of type 2 diabetes and its implications for breast cancer therapy. Although Michels et al. (2003) found type 2 diabetes to be a risk factor specifically for ER-positive postmenopausal breast cancer, and we have discussed the experimental support for an interaction between insulin and estrogens in the stimulation of breast cancer progression, Goodwin et al. (2012), when demonstrating an association between the fasting serum insulin, insulin resistance, and breast cancer prognosis, did not observe any modifying influence of ER status. The issue is one with important therapeutic implications. Gillespie et al. (2010) found that diabetes was associated with an increased risk for 'triple-negative' breast cancer, a tumor type that is negative for ER, PR, and HER2, possesses an aggressive metastatic phenotype, and has a poor prognosis. While this single report requires verification, the metabolic syndrome, with independent association for the blood glucose, has been associated with triple-negative breast cancer (Maiti et al. 2010).

\section{Declaration of interest}

The authors declare that there is no conflict of interest that could be perceived as prejudicing the impartiality of the research reported.

\section{Funding}

This research did not receive any specific grant from any funding agency in the public, commercial, or not-for-profit sector.

\section{Author contribution statement}

D P Rose participated in the drafting of this manuscript and he has seen and approved the final version. L Vona-Davis participated in the drafting of this manuscript and she has seen and approved the final version.

\section{Acknowledgements}

The authors would like to acknowledge Emily Ngan for her assistance with the figures.

\section{References}

American Cancer Society 2011 Cancer Facts and Figures 2010. Atlanta.

American Diabetic Association 2012 Diagnosis and classification of diabetes mellitus. Diabetes Care 35 (Suppl 1) S64-S71.

Barone I, Catalano S, Gelsomino L, Marsico S, Giordano C, Panza S, Bonofiglio D, Bossi G, Covington KR, Fuqua SAW et al. 2012 Leptin mediates tumor-stromal interactions that promote the invasive growth of breast cancer cells. Cancer Research 72 1416-1427. (doi:10.1158/0008-5472.CAN-11-2558)

Bartella V, Cascio S, Fiorio E, Auriemma A, Russo A \& Surmacz E 2008 Insulin-dependent leptin expression in breast cancer cells. Cancer Research 68 4919-4927. (doi:10.1158/0008-5472.CAN-08-0642)

Belfiore A \& Malaguarnera R 2011 Insulin receptor and cancer. Endocrine-Related Cancer 18 125-147. (doi:10.1530/ERC-11-0074)

Belfiore A, Costantino A, Frasca F, Pandini G, Mineo R, Vigneri P, Maddux B, Goldfine ID \& Vigneri R 1996 Overexpression of membrane glycoprotein PC-1 in MDA-MB-231 breast cancer cells is associated with inhibition of insulin receptor tyrosine kinase activity. Molecular Endocrinology 10 1318-1326. (doi:10.1210/ me.10.11.1318)

Belfiore A, Frasca F, Pandini G, Sciacca L \& Vigneri R 2009 Insulin receptor isoforms and insulin receptor/insulin-like growth factor receptor hybrids in physiology and disease. Endocrine Reviews 30 586-623. (doi:10.1210/er. 2008-0047) 
Bradley RL \& Cheatham B 1999 Regulation of ob gene expression and leptin secretion by insulin and dexamethasone in rat adipocytes. Diabetes 48 272-278. (doi:10.2337/diabetes.48.2.272)

van den Brandt PA, Spiegelman D, Yaun SS, Adami HO, Beeson L, Folsom AR, Fraser G, Goldbohm RA, Graham S, Kushi L et al. 2000 Pooled analysis of prospective cohort studies on height, weight, and breast cancer risk. American Journal of Epidemiology 152 514-527. (doi:10.1093/aje/152.6.514)

Brown KA, Hunger NI, Docanto M \& Simpson ER 2010 Metformin inhibits aromatase expression in human breast adipose stromal cells via stimulation of AMP-activated protein kinase. Breast Cancer Research and Treatment 123 591-596. (doi:10.1007/s10549-0100834-y)

Buck E, Gokhale PC, Koujak S, Brown E, Eyzaguirre A, Tao N, Rosenfeld-Franklin M, Lerner L, Chiu MI, Wild R et al. 2010 Compensatory insulin receptor (IR) activation on inhibition of insulin-like growth factor-1 receptor (IGF-1R): rationale for cotargeting IGF-1R and IR in cancer. Molecular Cancer Therapeutics 9 2652-2664. (doi:10.1158/1535-7163.MCT-10-0318)

Bulun SE, Chen D, Moy I, Brooks DC \& Zhao H 2012 Aromatase, breast cancer and obesity: a complex interaction. Trends in Endocrinology and Metabolism 23 83-89. (doi:10.1016/j.tem.2011.10.003)

Burwinkel B, Shanmugam KS, Hemminki K, Meindl A, Schmutzler RK, Sutter C, Wappenschmidt B, Kiechle M, Bartram CR \& Frank B 2006 Transcription factor 7-like 2 (TCF7L2) variant is associated with familial breast cancer risk: a case-control study. BMC Cancer 6268. (doi:10.1186/1471-2407-6-268)

Cao R, Brakenhielm E, Wahlestedt C, Thyberg J \& Cao Y 2001 Leptin induces vascular permeability and synergistically stimulates angiogenesis with FGF-2 and VEGF. PNAS 98 6390-6395. (doi:10.1073/pnas. 101564798)

Celis JE, Moreira JM, Cabezon T, Gromov P, Friis E, Rank F \& Gromova I 2005 Identification of extracellular and intracellular signaling components of the mammary adipose tissue and its interstitial fluid in high risk breast cancer patients: toward dissecting the molecular circuitry of epithelial-adipocyte stromal cell interactions. Molecular and Cellular Proteomics 4 492-522. (doi:10.1074/mcp.M500030-MCP200)

Chappell J, Leitner JW, Solomon S, Golovchenko I, Goalstone ML \& Draznin B 2001 Effect of insulin on cell cycle progression in MCF-7 breast cancer cells. Direct and potentiating influence. Journal of Biological Chemistry 276 38023-38028. (doi:10.1074/jbc. M106008200)

Cirillo D, Rachiglio AM, la Montagna R, Giordano A \& Normanno N 2008 Leptin signaling in breast cancer: an overview. Journal of Cellular Biochemistry 105 956-965. (doi:10.1002/jcb.21911)
Costantino A, Milazzo G, Giorgino F, Russo P, Goldfine ID, Vigneri R \& Belfiore A 1993 Insulin-resistant MDA-MB-231 human breast cancer cells contain a tyrosine kinase inhibiting activity. Molecular Endocrinology 7 1667-1676. (doi:10.1210/me.7.12.1667)

Cowie CC, Rust KF, Byrd-Holt DD, Eberhardt MS, Flegal KM, Engelgau MM, Saydah SH, Williams DE, Geiss LS \& Gregg EW 2006 Prevalence of diabetes and impaired fasting glucose in adults in the U.S. population: National Health and Nutrition Examination Survey 1999-2002. Diabetes Care 29 1263-1268. (doi:10.2337/ dc06-0062)

Desbois-Mouthon C, Cadoret A, Blivet-Van Eggelpoel MJ, Bertrand F, Caron M, Atfi A, Cherqui G \& Capeau J 2000 Insulin-mediated cell proliferation and survival involve inhibition of c-Jun N-terminal kinases through a phosphatidylinositol 3-kinase- and mitogen-activated protein kinase phosphatase-1-dependent pathway. Endocrinology 141 922-931. (doi:10.1210/en.141.3.922)

Dieudonne MN, Bussiere M, Dos Santos E, Leneveu MC, Giudicelli Y \& Pecquery R 2006 Adiponectin mediates antiproliferative and apoptotic responses in human MCF7 breast cancer cells. Biochemical and Biophysical Research Communications 345 271-279. (doi:10.1016/j. bbrc.2006.04.076)

Ding EL, Song Y, Manson JE, Rifai N, Buring JE \& Liu S 2007 Plasma sex steroid hormones and risk of developing type 2 diabetes in women: a prospective study. Diabetologia 50 2076-2084. (doi:10.1007/s00125-0070785-y)

Dos Santos E, Benaitreau D, Dieudonne MN, Leneveu MC, Serazin V, Giudicelli Y \& Pecquery R 2008 Adiponectin mediates an antiproliferative response in human MDA-MB 231 breast cancer cells. Oncology Reports 20 971-977.

Dowling RJ, Zakikhani M, Fantus IG, Pollak M \& Sonenberg N 2007 Metformin inhibits mammalian target of rapamycin-dependent translation initiation in breast cancer cells. Cancer Research 67 10804-10812. (doi:10.1158/0008-5472.CAN-07-2310)

Draznin B 2011 Mechanism of the mitogenic influence of hyperinsulinemia. Diabetology \& Metabolic Syndrome 13 10. (doi:10.1186/1758-5996-3-10)

Duggan C, Irwin ML, Xiao L, Henderson KD, Smith AW, Baumgartner RN, Baumgartner KB, Bernstein L, Ballard-Barbash R \& McTiernan A 2011 Associations of insulin resistance and adiponectin with mortality in women with breast cancer. Journal of Clinical Oncology 29 32-39. (doi:10.1200/JCO.2009.26.4473)

Fain JN \& Madan AK 2005 Insulin enhances vascular endothelial growth factor, interleukin-8, and plasminogen activator inhibitor 1 but not interleukin-6 release from human adipocytes. Metabolism 54 220-226. (doi:10.1016/j.metabol.2004.08.016)

Fasshauer M, Klein J, Neumann S, Eszlinger M \& Paschke R 2002 Hormonal regulation of adiponectin gene expression 
in 3T3-L1 adipocytes. Biochemical and Biophysical Research Communications 290 1084-1089. (doi:10.1006/ bbrc.2001.6307)

Ferrara N 2001 Role of vascular endothelial growth factor in regulation of physiological angiogenesis. American Journal of Physiology. Cell Physiology 280 C1358-C1366. (doi:10.1159/000046610)

Festa A, Williams K, D’Agostino R Jr, Wagenknecht LE \& Haffner SM 2006 The natural course of $\beta$-cell function in nondiabetic and diabetic individuals: the Insulin Resistance Atherosclerosis Study. Diabetes 55 1114-1120. (doi:10.2337/diabetes.55.04.06.db05-1100)

Fierz Y, Novosyadlyy R, Vijayakumar A, Yakar S \& LeRoith D 2010 Mammalian target of rapamycin inhibition abrogates insulin-mediated mammary tumor progression in type 2 diabetes. Endocrine-Related Cancer 17 941-951. (doi:10.1677/ERC-10-0091)

Fischer S, Hanefeld M, Haffner SM, Fusch C, Schwanebeck U, Kohler C, Fucker K \& Julius U 2002 Insulin-resistant patients with type 2 diabetes mellitus have higher serum leptin levels independently of body fat mass. Acta Diabetologia 39 105-110. (doi:10.1007/ s005920200027)

Fruhbeck G 2006 Intracellular signaling pathways activated by leptin. Biochemical Journal 393 7-20. (doi:10.1042/ BJ20051578)

Gallagher EJ \& LeRoith D 2010 The proliferating role of insulin and insulin-like growth factors in cancer. Trends in Endocrinology and Metabolism 21 610-618. (doi:10.1016/j.tem.2010.06.007)

Gallagher EJ, Fierz Y, Vijayakumar A, Haddad N, Yakar S \& LeRoith D 2011 Inhibiting PI3K reduces mammary tumor growth and induces hyperglycemia in a mouse model of insulin resistance and hyperinsulinemia. Oncogene 31 3213-3222 (doi: 10.1038/onc.2011.495). (doi:10.1038/ onc.2011.495)

Garofalo C, Koda M, Cascio S, Sulkowska M, Kanczuga-Koda L, Golaszewska J, Russo A, Sulkowski S \& Surmacz E 2006 Increased expression of leptin and the leptin receptor as a marker of breast cancer progression: possible role of obesity-related stimuli. Clinical Cancer Research 12 1447-1453. (doi:10.1158/1078-0432.CCR05-1913)

Gillespie EF, Sorbero ME, Hanauer DA, Sabel MS, Herrmann EJ, Weiser LJ, Jagielski CH \& Griggs JJ 2010 Obesity and angiolymphatic invasion in primary breast cancer. Annals of Surgical Oncology 17 752-759. (doi:10.1245/s10434-009-0797-6)

Gliozzo B, Sung CK, Scala P, Papa V, Frasca F, Sciacca L, Giorgino F, Milazzo G, Goldfine ID, Vigneri R et al. 1998 Insulin-stimulated cell growth in insulin receptor substrate-1-deficient ZR-75-1 cells is mediated by a phosphatidylinositol-3-kinase-independent pathway. Journal of Cellular Biochemistry 70 268-280. (doi:10.1002/(SICI)1097-4644(19980801)70:2<268:: AID-JCB12>3.0.CO;2-J)
Golden SH, Dobs AS, Vaidya D, Szklo M, Gapstur S, Kopp P, Liu K \& Ouyang P 2007 Endogenous sex hormones and glucose tolerance status in postmenopausal women. Journal of Clinical Endocrinology and Metabolism 92 1289-1295. (doi:10.1210/jc.2006-1895)

Goldfine ID, Maddux BA, Youngren JF, Reaven G, Accili D, Trischitta V, Vigneri R \& Frittitta L 2008 The role of membrane glycoprotein plasma cell antigen 1/ectonucleotide pyrophosphatase phosphodiesterase 1 in the pathogenesis of insulin resistance and related abnormalities. Endocrine Reviews 29 62-75. (doi:10.1210/er.20070004)

Goodwin PJ, Ennis M, Pritchard KI, Trudeau ME, Koo J, Madarnas Y, Hartwick W, Hoffman B \& Hood N 2002 Fasting insulin and outcome in early-stage breast cancer: results of a prospective cohort study. Journal of Clinical Oncology 20 42-51. (doi:10.1200/JCO.20.1.42)

Goodwin PJ, Ennis M, Bahl M, Fantus IG, Pritchard KI, Trudeau ME, Koo J \& Hood N 2009 High insulin levels in newly diagnosed breast cancer patients reflect underlying insulin resistance and are associated with components of the insulin resistance syndrome. Breast Cancer Research and Treatment 114 517-525. (doi:10.1007/s10549-0080019-0)

Goodwin PJ, Ennis M, Pritchard KI, Trudeau ME, Koo J, Taylor SK \& Hood N 2012 Insulin- and obesity-related variables in early-stage breast cancer: correlations and time course of prognostic associations. Journal of Clinical Oncology 30 164-171. (doi:10.1200/JCO.2011.36.2723)

Guillausseau PJ, Meas T, Virally M, Laloi-Michelin M, Medeau V \& Kevorkian JP 2008 Abnormalities in insulin secretion in type 2 diabetes mellitus. Diabetes and Metabolism 34 (Suppl 2) S43-S48. (doi:10.1016/S12623636(08)73394-9)

Gunter MJ, Hoover DR, Yu H, Wassertheil-Smoller S, Rohan TE, Manson JE, Li J, Ho GY, Xue X, Anderson GL et al. 2009 Insulin, insulin-like growth factor-I, and risk of breast cancer in postmenopausal women. Journal of the National Cancer Institute 101 48-60. (doi:10.1093/jnci/ djn415)

Gupta PB \& Kuperwasser C 2006 Contributions of estrogen to ER-negative breast tumor growth. Journal of Steroid Biochemistry and Molecular Biology 102 71-78. (doi:10.1016/j.jsbmb.2006.09.025)

Haffner SM, Valdez RA, Morales PA, Hazuda HP \& Stern MP 1993 Decreased sex hormone-binding globulin predicts noninsulin-dependent diabetes mellitus in women but not in men. Journal of Clinical Endocrinology and Metabolism 77 56-60. (doi:10.1210/jc.77.1.56)

Haluzik M, Parizkova J \& Haluzik MM 2004 Adiponectin and its role in the obesity-induced insulin resistance and related complications. Physiological Research 53 123-129.

Hernandez-Aya LF \& Gonzalez-Angulo AM 2011 Targeting the phosphatidylinositol 3-kinase signaling pathway in breast cancer. Oncologist 16 404-414. (doi:10.1634/ theoncologist.2010-0402) 
Hou WK, Xu YX, Yu T, Zhang L, Zhang WW, Fu CL, Sun Y, Wu Q \& Chen L 2007 Adipocytokines and breast cancer risk. Chinese Medical Journal 120 1592-1596.

Hursting SD, Nunez NP, Varticovski L \& Vinson C 2007 The obesity-cancer link: lessons learned from a fatless mouse. Cancer Research 67 2391-2393. (doi:10.1158/00085472.CAN-06-4237)

Jiang ZY, He Z, King BL, Kuroki T, Opland DM, Suzuma K, Suzuma I, Ueki K, Kulkarni RN, Kahn CR et al. 2003 Characterization of multiple signaling pathways of insulin in the regulation of vascular endothelial growth factor expression in vascular cells and angiogenesis. Journal of Biological Chemistry 278 31964-31971. (doi:10.1074/ jbc.M303314200)

Johnson JA, Carstensen B, Witte D, Bowker SL, Lipscombe L \& Renehan AG 2012 Diabetes and cancer (1): evaluating the temporal relationship between type 2 diabetes and cancer incidence. Diabetologia $\mathbf{5 5}$ 1607-1618. (doi:10.1007/s00125-012-2525-1)

Kaaks R, Rinaldi S, Key TJ, Berrino F, Peeters PH, Biessy C, Dossus L, Lukanova A, Bingham S, Khaw KT et al. 2005 Postmenopausal serum androgens, oestrogens and breast cancer risk: the European prospective investigation into cancer and nutrition. Endocrine-Related Cancer 12 1071-1082. (doi:10.1677/erc.1.01038)

Kabat GC, Kim M, Caan BJ, Chlebowski RT, Gunter MJ, Ho GY, Rodriguez BL, Shikany JM, Strickler HD, Vitolins MZ et al. 2009 Repeated measures of the serum glucose and insulin in relation to postmenopausal breast cancer. International Journal of Cancer 125 2704-2710. (doi:10.1002/ijc.24609)

Kalyani RR, Franco M, Dobs AS, Ouyang P, Vaidya D, Bertoni A, Gapstur SM \& Golden SH 2009 The association of endogenous sex hormones, adiposity, and insulin resistance with incident diabetes in postmenopausal women. Journal of Clinical Endocrinology and Metabolism 94 4127-4135. (doi:10.1210/jc.2009-0910)

Katzenellenbogen BS \& Norman MJ 1990 Multihormonal regulation of the progesterone receptor in MCF-7 human breast cancer cells: interrelationships among insulin/insulin-like growth factor-I, serum, and estrogen. Endocrinology 126 891-898. (doi:10.1210/ endo-126-2-891)

Lahmann PH, Hoffmann K, Allen N, van Gils CH, Khaw KT, Tehard B, Berrino F, Tjonneland A, Bigaard J, Olsen A et al. 2004 Body size and breast cancer risk: findings from the European Prospective Investigation into Cancer and Nutrition (EPIC). International Journal of Cancer 111 762-771. (doi:10.1002/ijc.20315)

Larsson SC, Mantzoros CS \& Wolk A 2007 Diabetes mellitus and risk of breast cancer: a meta-analysis. International Journal of Cancer 121 856-862. (doi:10.1002/ijc.22717)

Le Bacquer O, Shu L, Marchand M, Neve B, Paroni F, Kerr Conte J, Pattou F, Froguel P \& Maedler K 2011 TCF7L2 splice variants have distinct effects on $\beta$-cell turnover and function. Human Molecular Genetics 20 1906-1915. (doi:10.1093/hmg/ddr072)
Lindstedt G, Lundberg PA, Lapidus L, Lundgren H, Bengtsson C \& Bjorntorp P 1991 Low sex-hormonebinding globulin concentration as independent risk factor for development of NIDDM, 12-year follow-up of population study of women in Gothenberg, Sweden. Diabetes 40 123-128. (doi:10.2337/diabetes.40.1.123)

Liu Y, Petreaca M \& Martins-Green M 2009 Cell and molecular mechanisms of insulin-induced angiogenesis. Journal of Cellular and Molecular Medicine $\mathbf{1 3}$ 4492-4504. (doi:10.1111/j.1582-4934.2008.00555.x)

Lundgren H, Bengtsson C, Blohme G, Lapidis L \& Waldenstrom J 1990 Fasting serum insulin concentration and early insulin response as risk determinants for developing diabetes. Diabetic Medicine 7 407-413. (doi:10.1111/j.1464-5491.1990.tb01415.x)

Maiti B, Kundranda MN, Spiro TP \& Daw HA 2010 The association of metabolic syndrome with triple-negative breast cancer. Breast Cancer Research and Treatment 121 479-483. (doi:10.1007/s10549-009-0591-y)

Malaguarnera R, Sacco A, Voci C, Pandini G, Vigneri R \& Belfiore A 2012 Proinsulin binds with high affinity the insulin receptor isoform A and predominantly activates the mitogenic pathway. Endocrinology 153 2152-2163. (doi:10.1210/en.2011-1843)

Mantzoros C, Petridou E, Dessypris N, Chavelas C, Dalamaga M, Alexe DM, Papadiamantis Y,

Markopoulos C, Spanos E, Chrousos G et al. 2004 Adiponectin and breast cancer risk. Journal of Clinical Endocrinology and Metabolism 89 1102-1107. (doi:10. 1210/jc.2003-031804)

Mauro L, Salerno M, Panno ML, Bellizzi D, Sisci D, Miglietta A, Surmacz E \& Ando S 2001 Estradiol increases IRS-I gene expression and insulin signaling in breast cancer cells. Biochemical and Biophysical Research Communications 288 685-689. (doi:10.1006/ bbrc.2001.5815)

McTernan PG, Anwar A, Eggo MC, Barnett AH, Stewart PM \& Kumar S 2000 Gender differences in the regulation of P450 aromatase expression and activity in human adipose tissue. International Journal of Obesity and Related Metabolic Disorders 24 875-881. (doi:10.1038/sj.ijo. 0801254)

Merlo GR, Basolo F, Fiore L, Duboc L \& Hynes NE 1995 p53-dependent and p53-independent activation of apoptosis in mammary epithelial cells reveals a survival function of EGF and insulin. Journal of Cell Biology 128 1185-1196. (doi:10.1083/jcb.128.6.1185)

Michels KB, Solomon CG, Hu FB, Rosner BA, Hankinson SE, Colditz GA \& Manson JE 2003 Type 2 diabetes and subsequent incidence of breast cancer in the Nurses' Health Study. Diabetes Care 26 1752-1758. (doi:10.2337/diacare.26.6.1752)

Mick GJ, Wang X \& McCormick K 2002 White adipocyte vascular endothelial growth factor: regulation by insulin. Endocrinology 143 948-953. (doi:10.1210/en.143.3.948)

Miki Y, Suzuki T, Tazawa C, Yamaguchi Y, Kitada K, Honma S, Moriya T, Hirakawa H, Evans DB, Hayashi S 
et al. 2007 Aromatase localization in human breast cancer tissues: possible interactions between intratumoral stromal and parenchymal cells. Cancer Research 67 3945-3954. (doi:10.1158/0008-5472.CAN-06-3105)

Milazzo G, Giorgino F, Damante G, Sung C, Stampfer MR, Vigneri R, Goldfine ID \& Belfiore A 1992 Insulin receptor expression and function in human breast cancer cell lines. Cancer Research 52 3924-3930.

Miyazawa-Hoshimoto S, Takahashi K, Bujo H, Hashimoto N \& Saito Y 2003 Elevated serum vascular endothelial growth factor is associated with visceral fat accumulation in human obese subjects. Diabetologia 46 1483-1488. (doi:10.1007/s00125-003-1221-6)

Miyazawa-Hoshimoto S, Takahashi K, Bujo H, Hashimoto N, Yagui K \& Saito Y 2005 Roles of degree of fat deposition and its location on VEGF expression in adipocytes. American Journal of Physiology. Endocrinology and Metabolism 288 E1128-E1136. (doi:10.1152/ajpendo. 00003.2004)

Miyoshi Y, Funahashi T, Kihara S, Taguchi T, Tamaki Y, Matsuzawa Y \& Noguchi S 2003 Association of serum adiponectin levels with breast cancer. Clinical Cancer Research 9 5699-5704.

Mulligan AM, O’Malley FP, Ennis M, Fantus IG \& Goodwin PJ 2007 Insulin receptor is an independent predictor of a favorable outcome in early stage breast cancer. Breast Cancer Research and Treatment 106 39-47. (doi:10.1007/s10549-006-9471-x)

Naidu R, Yip CH \& Taib NA 2011 Genetic variations in transcription factor 7-like 2 (TCF7L2) gene: association of TCF7L2 rs12255372(G/T) or rs7903146(C/T) with breast cancer risk and clinico-pathological parameters. Medical Oncology 29 411-417. (doi:10.1007/s12032011-9837-8)

Norton L, Fourcaudot M, Abdul-Ghani MA, Winnier D, Mehta FF, Jenkinson CP \& Defronzo RA 2011 Chromatin occupancy of transcription factor 7-like 2 (TCF7L2) and its role in hepatic glucose metabolism. Diabetologia 54 3132-3142. (doi:10.1007/s00125-011-2289-z)

Novosyadlyy R, Lann DE, Vijayakumar A, Rowzee A, Lazzarino DA, Fierz Y, Carboni JM, Gottardis MM, Pennisi PA, Molinolo AA et al. 2010 Insulin-mediated acceleration of breast cancer development and progression in a nonobese model of type 2 diabetes. Cancer Research 70 741-751. (doi:10.1158/0008-5472.CAN-09-2141)

Ogasawara M \& Sirbasku DA 1988 A new serum-free method of measuring growth factor activities for human breast cancer cells in culture. In Vitro Cellular \& Developmental and Biology 24 911-920. (doi:10.1007/ BF02623902)

Osborne CK, Monaco ME, Lippman ME \& Kahn CR 1978 Correlation among insulin binding, degradation, and biological activity in human breast cancer cells in longterm tissue culture. Cancer Research 38 94-102.

Panno ML, Salerno M, Pezzi V, Sisci D, Maggiolini M, Mauro L, Morrone EG \& Ando S 1996 Effect of oestradiol and insulin on the proliferative pattern and on oestrogen and progesterone receptor contents in MCF-7 cells. Journal of Cancer Research and Clinical Oncology 122 745-749. (doi:10.1007/BF01209122)

Park D, Pandey SK, Maksimova E, Kole S \& Bernier M 2000 Akt-dependent antiapoptotic action of insulin is sensitive to farnesyltransferase inhibitor. Biochemistry 39 12513-12521. (doi:10.1021/bi000995y)

Peairs KS, Barone BB, Snyder CF, Yeh HC, Stein KB, Derr RL, Brancati FL \& Wolff AC 2011 Diabetes mellitus and breast cancer outcomes: a systematic review and meta-analysis. Journal of Clinical Oncology 29 40-46. (doi:10.1200/JCO.2009.27.3011)

Perera CN, Chin HG, Duru N \& Camarillo IG 2008 Lepinregulated gene expression in MCF-7 breast cancer cells: mechanistic insights into leptin-regulated mammary tumor growth and progression. Journal of Endocrinology 199 221-233. (doi:10.1677/JOE-08-0215)

Pfutzner A, Kunt T, Hohberg C, Mondok A, Pahler S, Konrad T, Lubben G \& Forst T 2004 Fasting intact proinsulin is a highly specific predictor of insulin resistance in type 2 diabetes. Diabetes Care 27 682-687. (doi:10.2337/diacare.27.3.682)

Rensing KL, Houttuijn Bloemendaal FM, Weijers EM, Richel DJ, Buller HR, Koolwijk P, van der Loos CM, Twickler TB \& von der Thusen JH 2010 Could recombinant insulin compounds contribute to adenocarcinoma progression by stimulating local angiogenesis? Diabetologia 53 966-970. (doi:10.1007/s00125-0101687-y)

Ribatti D 2011 Novel angiogenesis inhibitors: addressing the issue of redundancy in the angiogenic signaling pathway. Cancer Treatment Reviews 37 344-352. (doi:10.1016/j. ctrv.2011.02.002)

Rose DP 1993 Diet, hormones, and cancer. Annual Review of Public Health 14 1-17. (doi:10.1146/annurev.pu.14. 050193.000245)

Rose DP, Komninou D \& Stephenson GD 2004 Obesity, adipocytokines, and insulin resistance in breast cancer. Obesity Reviews 5 153-165. (doi:10.1111/j.1467-789X. 2004.00142.x)

Sasano H, Suzuki T, Nakata T \& Moriya T 2006 New development in intracrinology of breast carcinoma. Breast Cancer 13 129-136. (doi:10.2325/jbcs.13.129)

Sawatsri S, Samid D, Malkapuram S \& Sidell N 2001 Inhibition of estrogen-dependent breast cancer responses with phenylacetate. International Journal of Cancer 93 687-692. (doi:10.1002/ijc.1399)

Sciacca L, Costantino A, Pandini G, Mineo R, Frasca F, Scalia P, Sbraccia P, Goldfine ID, Vigneri R \& Belfiore A 1999 Insulin receptor activation by IGF-II in breast cancers: evidence for a new autocrine/paracrine mechanism. Oncogene 18 2471-2479. (doi:10.1038/sj. onc.1202600)

Sepp-Lorenzino L, Rosen N \& Lebwohl DE 1994 Insulin and insulin-like growth factor signaling are defective in the MDA-MB-468 human breast cancer cell line. Cell Growth \& Differentiation 5 1077-1083. 
Sieri S, Muti P, Claudia A, Berrino F, Pala V, Grioni S, Abagnato CA, Blandino G, Contiero P, Schunemann HJ et al. 2012 Prospective study on the role of glucose metabolism in breast cancer occurrence. International Journal of Cancer 130 921-929. (doi:10.1002/ijc.26071)

Sisci D, Morelli C, Garofalo C, Romeo F, Morabito L, Casaburi F, Middea E, Cascio S, Brunelli E, Ando S et al. 2007 Expression of nuclear insulin receptor substrate 1 in breast cancer. Journal of Clinical Pathology 60 633-641. (doi:10.1136/jcp.2006.039107)

Statnick MA, Beavers LS, Conner LJ, Corominola H, Johnson D, Hammond CD, Rafaeloff-Phail R, Seng T, Suter TM, Sluka JP et al. 2000 Decreased expression of apM1 in omental and subcutaneous adipose tissue of humans with type 2 diabetes. International Journal of Experimental Diabetes Research 1 81-88. (doi:10.1155/ EDR.2000.81)

Teng JA, Hou RL, Li DL, Yang RP \& Qin J 2011 Glargine promotes proliferation of breast adenocarcinoma cell line MCF-7 via AKT activation. Hormone and Metabolic Research 43 519-523. (doi:10.1055/s-0031-1280780)

Tian YF, Chu CH, Wu MH, Chang CL, Yang T, Chou YC, Hsu GC, Yu CP, Yu JC \& Sun CA 2007 Anthropometric measures, plasma adiponectin, and breast cancer. Endocrine-Related Cancer 14 669-677. (doi:10.1677/ ERC-06-0089)

Tworoger SS, Eliassen AH, Kelesidis T, Colditz GA, Willett WC, Mantzoros CS \& Hankinson SE 2007 Plasma adiponectin concentrations and risk of incident breast cancer. Journal of Clinical Endocrinology and Metabolism 92 1510-1516. (doi:10.1210/jc.2006-1975)

Uzzan B, Nicolas P, Cucherat M \& Perret GY 2004 Microvessel density as a prognostic factor in women with breast cancer: a systematic review of the literature and meta-analysis. Cancer Research 64 2941-2955. (doi:10.1158/0008-5472.CAN-03-1957)

Veikkola T \& Alitalo K 1999 VEGFs, receptors and angiogenesis. Seminars in Cancer Biology 9 211-220. (doi:10.1006/scbi.1998.0091)

Vigneri P, Frasca F, Sciacca L, Pandini G \& Vigneri R 2009 Diabetes and cancer. Endocrine-Related Cancer 16 1103-1123. (doi:10.1677/ERC-09-0087)

Vona-Davis L \& Rose DP 2007 Adipokines as endocrine, paracrine, and autocrine factors in breast cancer risk and progression. Endocrine-Related Cancer 14 189-206. (doi:10.1677/ERC-06-0068)

Vona-Davis L \& Rose DP 2009 Angiogenesis, adiponectins and breast cancer. Cytokine \& Growth Factor Reviews 20 193-201. (doi:10.1016/j.cytogfr.2009.05.007)

Vona-Davis L \& Rose DP 2012 Type 2 diabetes and obesity metabolic interactions: common factors for breast cancer risk and novel approaches to prevention and therapy. Current Diabetes Reviews 8 116-130. (doi:10.2174/ 157339912799424519)

Wang Y, Lam JB, Lam KS, Liu J, Lam MC, Hoo RL, Wu D, Cooper GJ \& Xu A 2006 Adiponectin modulates the glycogen synthase kinase- $3 \beta / \beta$-catenin signaling pathway and attenuates mammary tumorigenesis of MDA-MB-231 cells in nude mice. Cancer Research 66 11462-11470. (doi:10.1158/0008-5472.CAN-06-1969)

Wang Y, Hua S, Tian W, Zhang L, Zhao J, Zhang H, Zhang W \& Xue F 2012 Mitogenic and anti-apoptotic effects of insulin in endometrial cancer are phosphatidylinositol 3-kinase/Akt dependent. Gynecologic Oncology 125 734-741. (doi:10.1016/j.ygyno.2012.03.012)

Wauters M, Considine RV, Yudkin JS, Peiffer F, De Leeuw I \& Van Gaal LF 2003 Leptin levels in type 2 diabetes: associations with measures of insulin resistance and insulin secretion. Hormone and Metabolic Research 35 92-96. (doi:10.1055/s-2003-39054)

Weyer C, Funahashi T, Tanaka S, Hotta K, Matsuzawa Y, Pratley RE \& Tataranni PA 2001 Hypoadiponectinemia in obesity and type 2 diabetes: close association with insulin resistance and hyperinsulinemia. Journal of Clinical Endocrinology and Metabolism 86 1930-1935. (doi:10. 1210/jc.86.5.1930)

Willard AL \& Herman IM 2012 Vascular complications and diabetes: current therapies and future challenges. Journal of Opthalmology 2012 209538. (doi:10.1155/2012/209538)

Wolf I, Sadetzki S, Catane R, Karasik A \& Kaufman B 2005 Diabetes and breast cancer. Lancet Oncology 6 103-111. (doi:10.1016/S1470-2045(05)01736-5)

Xue F \& Michels KB 2007 Diabetes, metabolic syndrome, and breast cancer: a review of the current evidence. American Journal of Clinical Nutrition 86 s823-s835.

Yamagishi S, Kawakami T, Fujimori H, Yonekura H, Tanaka N, Yamamoto Y, Urayama H, Watanabe Y \& Yamamoto H 1999 Insulin stimulates the growth and tube formation of human microvascular endothelial cells through autocrine vascular endothelial growth factor. Microvascular Research 57 329-339. (doi:10.1006/mvre.1999.2145)

Zeggini E \& McCarthy MI 2007 TCF7L2: the biggest story in diabetes genetics since HLA? Diabetologia 50 1-4. (doi:10.1007/s00125-006-0507-x)

Zethelius B, Byberg L, Hales CN, Lithell H \& Berne C 2003 Proinsulin and acute insulin response independently predict type 2 diabetes mellitus in men-report from 27 years of follow-up study. Diabetologia 46 20-26. (doi:10.1007/s00125-002-0995-2)

Zhang H, Fagan DH, Zeng X, Freeman KT, Sachdev D \& Yee D 2010 Inhibition of cancer cell proliferation and metastasis by insulin receptor downregulation. Oncology 29 2517-2527.

Zhou HH, Chin CN, Wu M, Ni W, Quan S, Liu F, Dallas-Yang Q, Ellsworth K, Ho T, Zhang A et al. 2009 Suppression of PC1/ENPP-1 expression improves insulin sensitivity in vitro and in vivo. European Journal of Pharmacology 616 346-352. (doi:10.1016/j.ejphar.2009.06.057)

Received in final form 27 August 2012 Accepted 30 August 2012 Made available online as an Accepted Preprint 30 August 2012 